\title{
Maternal Hyperthyroidism and Pregnancy Complications
}

\author{
Ahmed RG* \\ Division of Anatomy and Embryology, Department of Zoology, Faculty of Science, Beni-Suef University, Egypt
}

Submission: March 05, 2018; Published: March 26, 2018

*Corresponding author: Ahmed RG, Department of Zoology, Beni-Suef University, Beni-Suef, Egypt, Tel: 002-010-91471828; Email: ahmedragab08@gmail.com

Keywords: Maternal hyperthyroidism; Pregnancy; Fetus

Abbreviations: THs: Thyroid Hormones; TSH: Thyroid-Stimulating Hormone; T3: 3,5,3'-triiodothyronine; T4: Thyroxine; HCG: Human Chorionic Gonadotropin; GTT: Gestational Transient Thyrotoxicosis; TRAb: TSH Receptor Anti Bodies

\section{Commentary}

The normal variations in the levels of maternal Thyroid Hormones (THs) throughout gestation are required for the normal development [1-60], in particular the metabolic homeostasis [60-62]. On the other hand, [63-75] classified the hyperthyroidism into three types as the following:

a. Thyrotoxicosis rising from the thyroid.

b. Overt hyperthyroidism is found when the concentration of the Thyroid-Stimulating Hormone (TSH) is in the normal range and the concentrations of the 3,5,3'-triodothyronine (T3) and free or total Thyroxine (T4) are above the normal range.

c. Subclinical hyperthyroidism is found when the concentration of the TSH is under the normal range and the concentrations of the $\mathrm{T} 3$ and free or total $\mathrm{T} 4$ are in the normal range.

As well, Glinoer [76] and [77-83] revealed that the Human Chorionic Gonadotropin (HCG) can stimulate the TSH receptor and cause Gestational Transient Thyrotoxicosis (GTT). Other etiologies of thyrotoxicosis during gestation including the following:

a. Hyperthyroidism of trophoblastic disease or symptomatic hyperthyroidism [84-91];

b. Disturbances in the genomic duplication of monospermic or dispermic fertilization and damage in the maternal nuclear genome [92];

c. Exogenous $\mathrm{TH}$, thyroiditis, toxic adenoma, toxic multinodular goiter, and Graves' disease [93,94]. Hyperreflexia, anxiety, tachycardia, heat intolerance, goiter, lack of weight gain, and palpitations are the most symptoms and signs of gestational thyrotoxicosis [95,96]. The signs of Graves' disease are ophthalmopathy or the presence of a goiter $[97,98]$. In dissimilarity, the symptoms of GTT are related to the persistent vomiting of hyperemesis gravidarum $[99,100]$.

On the other hand, number of examinations has revealed a relationship between the hyperthyroidism and an increase in the risk of pregnancy complications [101]. These complications were including the congestive heart failure, pre-eclampsia, miscarriage, pre-term delivery, hypertension or postpartum thyroiditis (thyroid inflammation). Also, intrauterine growth restriction and failure in neonatal growth are also associated with the goiter formation and maternal hyperthyroidism. More importantly, the elevation in the transportation of maternal TSH Receptor AntiBodies (TRAb) through placenta and lactation to fetuses and neonates can cause fetal and neonatal Graves' disease [102]. These disorders may delay the maternal and fetal outcomes. Thus, the prenatal care, antithyroid medications, and assessing TRAb levels at the late pregnancy may decrease these complications. Also, detection the nature and duration of the GTT symptoms may aid in the diagnostic decisions. Overall, the variations in the signs and symptoms of gestational hyperthyroidism make experimental studies essential.

\section{Conflict of Interest}

The author declares that no competing financial interests exist.

\section{References}

1. Aggarawal N, Suri V, Singla R, Chopra S, Sikka P, et al. (2014) Pregnancy outcome in hyperthyroidism: a case control study. Gynecol Obstet Invest 77(2): 94-99. 
2. Ahmed OM, Abd El-Tawab SM, Ahmed RG (2010) Effects of experimentally induced maternal hypothyroidism and hyperthyroidism on the development of rat offspring: I- The development of the thyroid hormones-neurotransmitters and adenosinergic system interactions. Int J Dev Neurosci 28(6): 437-454.

3. Ahmed OM, Ahmed RG (2012) Hypothyroidism. In A New Look At Hypothyroidism. In: Springer D (Eds.), Tech Open Access Publisher, Chapter 1, p. 1-20.

4. Ahmed OM, Ahmed RG, El-Gareib AW, El-Bakry AM, Abd El-Tawaba SM (2012) Effects of experimentally induced maternal hypothyroidism and hyperthyroidism on the development of rat offspring: II-The developmental pattern of neurons in relation to oxidative stress and antioxidant defense system. Int J Dev Neurosci 30(6): 517-537.

5. Ahmed OM, El-Gareib AW, El-bakry AM, Abd El-Tawab SM, Ahmed RG (2008) Thyroid hormones states and brain development interactions. Int J Dev Neurosci 26(2): 147-209.

6. Ahmed RG (2011) Perinatal 2,3,7,8-tetrachlorodibenzo-p-dioxin exposure alters developmental neuroendocrine system. Food Chem Toxicology 49: 1276-1284.

7. Ahmed RG (2012) Maternal-newborn thyroid dysfunction. In the Developmental Neuro endocrinology, pp. 1-369. Ahmed RG (Ed.) LAP LAMBERT Academic Publishing GmbH \& Co KG, Germany.

8. Ahmed RG (2012) Maternal-fetal thyroid interactions, Thyroid Hormone, Agrawal NK (Eds.), In Tech Open Access Publisher, Chapter 5, pp. $125-156$

9. Ahmed RG (2013) Early weaning PCB 95 exposure alters the neonatal endocrine system: thyroid adipokine dysfunction. J Endocrinol 219(3): 205-215.

10. Ahmed RG (2014) Editorial: Do PCBs modify the thyroid-adipokine axis during development? Annals Thyroid Res 1(1): 11-12.

11. Ahmed RG (2015) Chapter 1: Hypothyroidism and brain development In advances in hypothyroidism treatment. Avid Science Borsigstr 9, 10115 Berlin, Berlin, Germany. Avid Science Publications level 6, Melange Towers, Wing a, Hitec City, Hyderabad, Telangana, India $\mathrm{p}$. $1-40$.

12. Ahmed RG (2015) Hypothyroidism and brain developmental players. Thyroid Res J 8(2): 1-12.

13. Ahmed RG (2015) Editorials and Commentary: Maternofetal thyroid action and brain development J of Advances in Biology 7(1): 12071213.

14. Ahmed RG (2016) Gestational dexamethasone alters fetal neuroendocrine axis. Toxicol Lett 258: 46-54

15. Ahmed RG (2016) Neonatal polychlorinated biphenyls-induced endocrine dysfunction. Ann Thyroid Res 2(1): 34-35.

16. Ahmed RG (2016) Maternal iodine deficiency and brain disorders. Endocrinol Metab Syndr 5: 223.

17. Ahmed RG (2016) Maternal bisphenol A alters fetal endocrine system: Thyroid adipokine dysfunction. Food Chem Toxicology 95: 168-174.

18. Ahmed RG (2017) Developmental thyroid diseases and GABAergic dysfunction. EC Neurology 8(1): 2-4.

19. Ahmed RG (2017) Hyperthyroidism and developmental dysfunction. Arch Med 9: 4.

20. Ahmed RG (2017) Anti-thyroid drugs may be at higher risk for perinatal thyroid disease. EC Pharmacology and Toxicology 4(4): 140-142.

21. Ahmed RG (2017) Perinatal hypothyroidism and cytoskeleton dysfunction. Endocrinol Metab Syndr 6: 271.
22. Ahmed RG (2017) Developmental thyroid diseases and monoaminergic dysfunction. Advances in Applied Science Research 8(3): 1-10.

23. Ahmed RG (2017) Hypothyroidism and brain development. J Anim Res Nutr 2(2): 13.

24. Ahmed RG (2017) Antiepileptic drugs and developmental neuroendocrine dysfunction: Every why has A Wherefore. Arch Med $9(6): 2$.

25. Ahmed RG (2017) Gestational prooxidant-antioxidant imbalance may be at higher risk for postpartum thyroid disease. Endocrinol Metab Syndr 6: 279 .

26. Ahmed RG (2017) Synergistic actions of thyroid-adipokines axis during development. Endocrinol Metab Syndr 6: 280.

27. Ahmed RG (2017) Thyroid-insulin dysfunction during development. International Journal of Research Studies in Zoology 3(4): 73-75.

28. Ahmed RG (2017) Developmental thyroid diseases and cholinergic imbalance. International Journal of Research Studies in Zoology 3(4): 70-72.

29. Ahmed RG (2017) Thyroid diseases and developmental adenosinergic imbalance. Int J Clin Endocrinol 1(2): 53-55.

30. Ahmed RG (2017) Maternal anticancer drugs and fetal neuroendocrine dysfunction in experimental animals. Endocrinol Metab Syndr 6(6): 281.

31. Ahmed RG (2017) Letter: Gestational dexamethasone may be at higher risk for thyroid disease developing peripartum. Open Journal of Biomedical \& Life Sciences (Ojbili) 3(2): 1-6.

32. Ahmed RG (2017) Deiodinases and developmental hypothyroidism. EC Nutrition 11(5): 183-185.

33. Ahmed RG (2017) Maternofetal thyroid hormones and risk of diabetes. Int J of Res Studies in Medical and Health Sciences 2(10): 18-21.

34. Ahmed RG (2017) Association between hypothyroidism and renal dysfunctions. International Journal of Research Studies in Medical and Health Sciences 2(11): 1-4.

35. Ahmed RG (2017) Maternal hypothyroidism and lung dysfunction. International Journal of Research Studies in Medical and Health Sciences 2(11): 8-11.

36. Ahmed RG (2017) Endocrine disruptors; possible mechanisms for inducing developmental disorders. Int J basic Sci Medicine (IJBSM) 2(4): 157-160.

37. Ahmed RG (2017) Maternal thyroid hormones trajectories and neonatal behavioral disorders. ARC Journal of Diabetes and Endocrinology 3(2): 18-21.

38. Ahmed RG (2018) Maternal hypothyroidism and neonatal testicular dysfunction. International Journal of Research Studies in Medical and Health Sciences 3(1): 8-12.

39. Ahmed RG (2018) Maternal hypothyroidism and neonatal depression: Current perspective. International Journal of Research Studies in Zoology 4(1): 6-10.

40. Ahmed RG (2018) Non-genomic actions of thyroid hormones during development. App Clin Pharmacol Toxicol: ACPT-108.

41. Ahmed RG (2018) Maternal thyroid function and placental hemodynamics. ARC Journal of Animal and Veterinary Sciences 4(1): 9-13.

42. Ahmed RG (2018) Interactions between thyroid and growth factors during development. ARC Journal of Diabetes and Endocrinology 4(1): $1-4$. 
43. Ahmed RG (2018) Maternal thyroid hormones and neonatal appetite. ARC Journal of Nutrition and Growth 4(1): 18-22.

44. Ahmed RG (2018) Genomic actions of thyroid hormones during development. ARC Journal of Diabetes and Endocrinology 4(1): 5-8.

45. Ahmed RG (2018) Dysfunction of maternal thyroid hormones and psychiatric symptoms. American Research Journal of Endocrinology 2(1): 1-6.

46. Ahmed RG (2018) Is there a connection between maternal hypothyroidism and developing autism spectrum disorders? ARC Journal of Neuroscience 3(1): 5-8.

47. Ahmed RG (2018) Maternal thyroid dysfunctions and neonatal bone mal development. American Research Journal of Endocrinology (in press) $\mathrm{xx}-\mathrm{xxx}$.

48. Ahmed RG (2018) Maternal thyroid disorders and risk of neonatal seizure: Current perspective. ARC Journal of Neuroscience 3(1): 21-25.

49. Ahmed RG (2018) Gestational dioxin acts as developing neuroendocrine-disruptor. EC Pharmacology and Toxicology 6(3): 96100.

50. Ahmed RG (2018) Maternal thyroid dysfunction and risk of neonatal stroke. ARC Journal of Animal and Veterinary Sciences 4(1): 22-26.

51. Ahmed RG (2018n) Maternal thyroid disorders and developing skin dysfunctions. ARC Journal of Dermatology 3(1): 13-17.

52. Ahmed RG (2018) Maternal hypothyroidism-milk ejections: What is the link? ARC Journal of Nutrition and Growth 4(1): 29-33.

53. Ahmed RG (2018) Does maternal antepartum hypothyroidism cause fetal and neonatal hyponatremia? ARC Journal of Diabetes and Endocrinology 4(1): xx-xxx.

54. Ahmed RG (2018) Maternal hypothyroidism and rheumatoid arthritis International Journal of Research Studies in Medical and Health Sciences Volume 3(2): 1-5.

55. Ahmed RG (2018) Developmental thyroid and skeletal muscle dysfunction.ARC Journal of Diabetes and Endocrinology 4(1): xx-xxx.

56. Ahmed RG (2018) Hyperthyroidism and renal disorders. ARC Journal of Animal and Veterinary Sciences 4(2): 1-5.

57. Ahmed RG, Abdel-Latif M, Ahmed F (2015) Protective effects of GMCSF in experimental neonatal hypothyroidism. Int Immunopharmacol 29(2): 538-543

58. Ahmed RG, Abdel-Latif M, Mahdi E, El-Nesr K (2015) Immune stimulation improves endocrine and neural fetal outcomes in a model of maternofetal thyrotoxicosis. Int Immunopharmacol 29(2): 714-721.

59. Ahmed RG, Davis PJ, Davis FB, De Vito P, Farias RN, et al. (2013) Nongenomic actions of thyroid hormones: from basic research to clinical applications. An update. Immunology, Endocrine \& Metabolic Agents in Medicinal Chemistry 13(1): 46-59.

60. Ahmed RG, El-Gareib AW (2014) Lactating PTU exposure: I- Alters thyroid-neural axis in neonatal cerebellum. Eur J of Biol and Medical Sci Res 2(1): 1-16.

61. Ahmed RG, El-Gareib AW (2017) Maternal carbamazepine alters fetal neuroendocrine-cytokines axis. Toxicology 382: 59-66.

62. Ahmed RG, El-Gareib AW, Incerpi S (2014) Lactating PTU exposure: II- Alters thyroid-axis and prooxidant-antioxidant balance in neonatal cerebellum. Int Res J of Natural Sciences 2(1): 1-20.

63. Ahmed RG, El-Gareib AW, Shaker HM (2018) Gestational $3,3^{\prime}, 4,4^{\prime}, 5$-pentachlorobiphenyl (PCB 126) exposure disrupts fetoplacental unit: Fetal thyroid-cytokines dysfunction. Life Sciences 192: 213-220.
64. Ahmed RG, Incerpi S (2013) Gestational doxorubicin alters fetal thyroid-brain axis. Int J Dev Neurosci 31(2): 96-104.

65. Ahmed RG, Incerpi S, Ahmed F, Gaber A (2013) The developmental and physiological interactions between free radicals and antioxidant: Effect of environmental pollutants. J of Natural Sci Res 3(13): 74-110.

66. Ahmed RG, Walaa GH, Asmaa FS (2018) Suppressive effects of neonatal bisphenol A on the neuroendocrine system. Toxicology and Industrial Health Journal (in press).

67. Boelaert K, Torlinska B, Holder RL, Franklyn JA (2010) Older subjects with hyperthyroidism present with a paucity of symptoms and signs: a large crosssectional study. J Clin Endocrinol Metab 95(6): 2715-2726.

68. Candelotti E, De Vito P, Ahmed RG, Luly P, Davis PJ, et al. (2015) Thyroid hormones crosstalk with growth factors: Old facts and new hypotheses. Immun Endoc \& Metab. Agents in Med Chem 15: 71-85.

69. Glinoer D (2003) Management of hypo- and hyperthyroidism during pregnancy. Growth Horm IGF Res 13: S45-S54.

70. De Vito P, Candelotti E, Ahmed RG, Luly P, Davis PJ, et al. (2015) Role of thyroid hormones in insulin resistance and diabetes. Immun Endoc \& Metab Agents in Med Chem 15: 86-93.

71. El-bakry AM, El-Ghareeb AW, Ahmed RG (2010) Comparative study of the effects of experimentally-induced hypothyroidism and hyperthyroidism in some brain regions in albino rats. Int J Dev Neurosci 28(5): 371-389.

72. El-Ghareeb AA, El-Bakry AM, Ahmed RG, Gaber A (2016) Effects of zinc supplementation in neonatal hypothyroidism and cerebellar distortion induced by maternal carbimazole. Asian Journal of Applied Sciences 4(4): 1030-1040.

73. Feldt-Rasmussen U, Mathiesen ER (2011) Endocrine disorders in pregnancy: Physiological and hormonal aspects of pregnancy. Best Pract Res Clin Endocrinol Metab 25(6): 875-884.

74. Franklyn JA, Boelaert K (2012) Thyrotoxicosis. Lancet 379(9821): 1155-1166.

75. Gadsby R, Barnie-Adshead AM, Jagger C (1993) A prospective study of nausea and vomiting during pregnancy. Br J Gen Pract 43(371): 245248.

76. Glinoer D (1997) The regulation of thyroid function in pregnancy: pathways of endocrine adaptation from physiology to pathology. Endocr Rev 18(3): 404-433.

77. Goldman AM, Mestman JH (2011) Transient non-autoimmune hyperthyroidism of early pregnancy. J Thyroid Res 2011: 142413.

78. Hamada N, Momotani N, Ishikawa N, Noh Yoshimura J, Okamoto Y et al. (2011) Persistent high TRAb values during pregnancy predict increased risk of neonatal hyperthyroidism following radioiodine therapy for refractory hyperthyroidism. Endocr J 58(1): 55-58.

79. Incerpi S, Hsieh MT, Lin HY, Cheng GY, De Vito P, et al. (2014) Thyroid hormone inhibition in L6 myoblasts of IGF-I-mediated glucose uptake and proliferation: new roles for integrin $\alpha v \beta 3$. Am J Physiol Cell Physiol 307(2): C150-C161.

80. Kahr MK, Antony KM, DelBeccaro M, Hu M, Aagaard KM, et al. (2016) Increasing maternal obesity is associated with alterations in both maternal and neonatal thyroid hormone levels. Clinical Endocrinology 84(4): 551-557.

81. Kamijo K (2007) TSH-receptor antibodies determined by the first, second and third generation assays and thyroid-stimulating antibody in pregnant patients with Graves' disease. Endocr J 54(4): 619.

82. Knight BA, Shields BM, Hattersley AT, Vaidya B (2016) Maternal hypothyroxinaemia in pregnancy is associated with obesity and 
adverse maternal metabolic parameters. Eur J Endocrinol 174(1): 5157.

83. Kung AW, Chau MT, Lao TT, Tam SC, Low LC (2002) The effect of pregnancy on thyroid nodule formation. J Clin Endocrinol Metab 87(3): 1010-1014.

84. Labadzhyan A, Brent AG, Hershman JM, Leung AM (2014) Thyrotoxicosis of pregnancy. J Clin Translational Endocrinol 1(4): 140-144.

85. Lazarus JH, Premawardhana LD (2005) Screening for thyroid disease in pregnancy. J Clin Pathol 58(5): 449-452.

86. Levy-Shraga Y, Tamir-Hostovsky L, Boyko V, Lerner-Geva L, PinhasHamiel 0 (2014) Follow-up of newborns of mothers with Graves disease. Thyroid 24(6): 1032-1039.

87. Luetic AT, Miskovic B (2010) Is hyperthyroidism underestimated in pregnancy and misdiagnosed as hyperemesis gravidarum? Med Hypotheses 75(4): 383-386.

88. Luton D, Le Gac I, Vuillard E, Castanet M, Guibourdenche J, et al. (2005) Management of Graves' disease during pregnancy: the key role of fetal thyroid gland monitoring. J Clin Endocrinol Metab 90(11): 6093-6098.

89. Mannisto T, Mendola P, Grewal J, Xie Y, Chen Z, et al. (2013) Thyroid diseases and adverse pregnancy outcomes in a contemporary US cohort. J Clin Endocrinol Metab 98(7): 2725-2733.

90. Pearce EN (2015) Thyroid disorders during pregnancy and postpartum. Best Pract Res Clin Obstet Gynaecol 29(5): 700-706.

91. Pennacchio GE, Neira FJ, Soaje M, Jahn GA, Valdez SR (2017) Effect of hyperthyroidism on circulating prolactin and hypothalamic expression of tyrosine hydroxylase, prolactin signaling cascade members and estrogen and progesterone receptors during late pregnancy and lactation in the rat. Mol Cell Endocrinol 442: 40-50.

92. Seckl MJ, Sebire NJ, Fisher RA, Golfier F, Massuger L, et al. (2013) Gestational trophoblastic disease: ESMO clinical practice guidelines for diagnosis, treatment and follow-up. Ann Oncol 24(Suppl. 6): vi39-vi50.
93. Sheffield JS, Cunningham FG (2004) Thyrotoxicosis and heart failure that complicate pregnancy. Am J Obstet Gynecol 190(1): 211-217.

94. Surks MI, Ortiz E, Daniels GH, Sawin CT, Col NF, et al. (2004) Subclinical thyroid disease: scientific review and guidelines for diagnosis and management. JAMA 291(2): 228-238.

95. Tagami T, Hagiwara H, Kimura T, Usui T, Shimatsu A, et al. (2007) The incidence of gestational hyperthyroidism and postpartum thyroiditis in treated patients with Graves' disease. Thyroid 17(8): 767-772.

96. Tan JY, Loh KC, Yeo GS, Chee YC (2002) Transient hyperthyroidism of hyperemesis gravidarum. BJOG 109(6): 683-688.

97. Van Herck SLJ, Geysens S, Bald E, Chwatko G, Delezie E, et al. (2013) Maternal transfer of methimazole and effects on thyroid hormone availability in embryonic tissues. Endocrinol 218(1): 105-115.

98. Walkington L, Webster J, Hancock BW, Everard J, Coleman RE (2011) Hyperthyroidism and human chorionic gonadotrophin production in gestational trophoblastic disease. Br J Cancer 104(11): 1665-1669.

99. Wee L, Jauniaux E (2005) Prenatal diagnosis and management of twin pregnancies complicated by a co-existing molar pregnancy. Prenat Diagn 25(9): 772-776.

100. Weetman AP (2000) Graves' disease. N Engl J Med 343(17): 1236 1248.

101. Yeo CP, Khoo DH, Eng PH, Tan HK, Yo SL, et al. (2001) Prevalence of gestational thyrotoxicosis in Asian women evaluated in the 8th to $14^{\text {th }}$ weeks of pregnancy: correlations with total and free beta human chorionic gonadotrophin. Clin Endocrinol 55(3): 391-398.

102. Zimmerman D (1999) Fetal and neonatal hyperthyroidism. Thyroid 9(7): 727-733.

\section{Your next submission with Juniper Publishers} will reach you the below assets

- Quality Editorial service

- Swift Peer Review

- Reprints availability

- E-prints Service

- Manuscript Podcast for convenient understanding

- Global attainment for your research

- Manuscript accessibility in different formats

( Pdf, E-pub, Full Text, Audio)

- Unceasing customer service

Track the below URL for one-step submission https://juniperpublishers.com/online-submission.php 